\title{
Identification of Barriers Towards Change and Proposal to Institutionalize Continuous Improvement Programs in Manufacturing Operations
}

\author{
Alvair Silveira Torres Jr.',Ana María Gati²
}

\begin{abstract}
A multi case research unfolded into a study in a sample of Brazilian manufacturing companies concerning their Continuous Improvement $(\mathrm{Cl})$ program in manufacturing operations. Stakeholders interviews and performance analyses were conducted. The study aims to analyze the existence or absence of the institutionalization of a $\mathrm{Cl}$ culture in manufacturing operations, identify barriers and difficulties within the process and propose a model for change. As a result of the research, it was observed that despite the considerable motivation of staff, rapid gains of the company and superior results during the early phases of the $\mathrm{Cl}$ program, time and again such results were either not upheld or faded out over time, delivering no significant mid-term or long term results, due to poor management of changes. This happened mainly as a result of lack of strategic alignment at all levels of the organization, translated in measureable activities and projects, coached and mentored by the middle and upper management throughout the implementation and maintenance of the program. The selected cases showed a declining in performance after two years of $\mathrm{Cl}$ program start up. Learning, union and process ownership among participants by means of interactions, are necessary to absorb and incorporate changes, instead of merely "smart words".
\end{abstract}

Keywords: Manufacturing; continuous improvement; change management.

\footnotetext{
'Assistant Professor. University of São Paulo,Av Prof. Luciano Gualberto,908, São Paulo SP, Brasil. Phone: 55 II 309 I-5842 Email:alvair@usp.br ${ }^{2}$ Aspirant to PhD program. University of São Paulo.Av Prof. Luciano Gualberto, 908, São Paulo SP, Brasil. Phone: 55 II 309 I-5842 Email:ana.gati@uol.com.br
} 


\section{Introduction}

The spread of lean concepts published in the 90's (Womack, Jones, Roos ,1990), in the book "The Machine That Changed the World" as well as in "Lean Thinking" (Womack \& Jones, 1996), called the attention of many businesses in their thirst for knowledge and eagerness to adapt such concepts to their business. The learning and success of the Toyota automobile company in Lean Management have become familiar terms in business environments, especially of industrial operations, introducing concepts such as Kaizen, lean manufacturing, kanban, poka yoke, industrial cellular arrangement, mapping the value stream (VSM-value stream mapping).

Among these concepts, the Kaizen system appears as a synonym for Continuous Improvement Program (CIP); nevertheless it is important to note that the word Kaizen in Japanese, means continuous improvement through actions to address a problem and, before helping to create a system, it was used in the form of isolated actions, not sufficient, though, to promote behavior change in the organization. When discussing the term "Continuous Improvement Program" or CIP, this includes Kaizen events or initiatives, in addition to a much larger process that touches the boundaries of the $\mathrm{Cl}$ with innovation, knowledge management, organizational learning, but with the advantage of bringing all these concepts together in a practical program of action, which fosters commitment and change in people's attitudes. Thus $\mathrm{Cl}$ would be all dissemination and application of knowledge in changes in performance of internal processes, with improved standards and group learning. This way, a new level of improvements in subsequent cycles is prepared.

The advancement in productivity and efficiency of manufacturing industries, akin to the Toyota model, has followed the principles of Continuous Improvement $(\mathrm{Cl})$, through innovation in production processes in a steady way, gradual and frequent, continuously. This change in the way work is performed provided an environment of organizational learning in a broad way in many corporations (Chen \& Wu, 2006), (Caffyn, 1999), (Delbridge \& Barton, 2002). The literature cited refers to practices embedded in Western culture, originating nonetheless, from Confucianism that has influenced the myth of the founding of a new production system at Toyota, which has as its goal the pursuit of perfection and the elimination of waste, according to quotes and book by Ohno(1988).
Given the recent economic crisis of 2008, many companies that always stood out in their manufacturing operations, such as Toyota, have also been facing challenges in their business, but a leading expert on Japanese manufacturing (Fujimoto, 1999), argues that knowledge and $\mathrm{Cl}$ practice already absorbed by the organization will be the basis and leverage of future production processes for products with more complex design.

On the other hand, the new phase of capitalism embodied in new and different patterns of consumption that value a multiplicity or plurality of demands, having in the in innovation their common axis which manifests itself, on the one end, in the hardware of products with levels of embedded technology, more complexity ( Clark \& Fujimoto, 1991) regarding more features, more convergence and more control; and on the other end, demands more focus on the values of software, regarding sustainable products, more organic-friendly, healthier and, less invasive, that bring happiness and satisfaction with the routine and, finally more complex innovations to substances and the most intelligent elements that play more organic roles in symbiosis with human life.

This somewhat cyber picture does justice to the concept of knowledge society in the form of systems and ways of applying science to everyday life, seen as a means of producing goods and services that help in achieving this happy and comfortable life.

The concept in this macro approach makes sense, but in reality, organizations require the production of these goods in machinery and equipment to support this Eden of knowledge, and the need of processes and routines with a view to technical and economic feasibility for its spread in society.

Theoretical models of organizations of knowledge, learning, and innovation, coated with the features that this new world is to value, emerge in the literature (Nonaka \& Takeuchi, 1995), (Senge, 1990), (Nelson, 1987) and (Drucker, 1998). Even though these models have the merit of bringing in a strategic way to organize these new data and events, the fact is that they end up spreading easily at the top of the organization in senior management - who are producing beautiful reports with so-called smart words; however, the transition to production 
and operational and middle management, who need to translate these concepts into practice routine, has not been done so easily.

This is the evolution we refer to in Picture $I$ and the challenge facing the organizations that produce goods and services. There is no way to keep for long, an asynchrony between the world of innovation and an operation to be based on hierarchical ways of dealing with the changes making them bureaucratic, top-down and having low participation. Why? The answer is the cost to manage the changes, the implementation time and the reliability required. A structure that incorporates constant innovation, which enhances the identification of problems and the overcoming of them, that looks for improving standards and believes everyone's participation in the development of solutions, is a structure that theorists of organizational models have, for 30 or 40 years called an organizational structure, better suited to control and implement changes more quickly and at lower costs. If in the currency value of this structure we have, in concept, the idea of organicity, in the practical side, we have relations of continuous improvement. This is the concept that has evolved set in various organizational models from its strong foundation in the Toyota model, to terms somewhat bureaucratic in management systems such as ISO 900 I.

Therefore, in Picture I (by the authors) we illustrate the changes and future trends in production models. Companies that move to the next level of evolution and stage of development required by the context of the new economy, absorbing and institutionalizing $\mathrm{Cl}$ organically, will be better prepared for a new level of change.

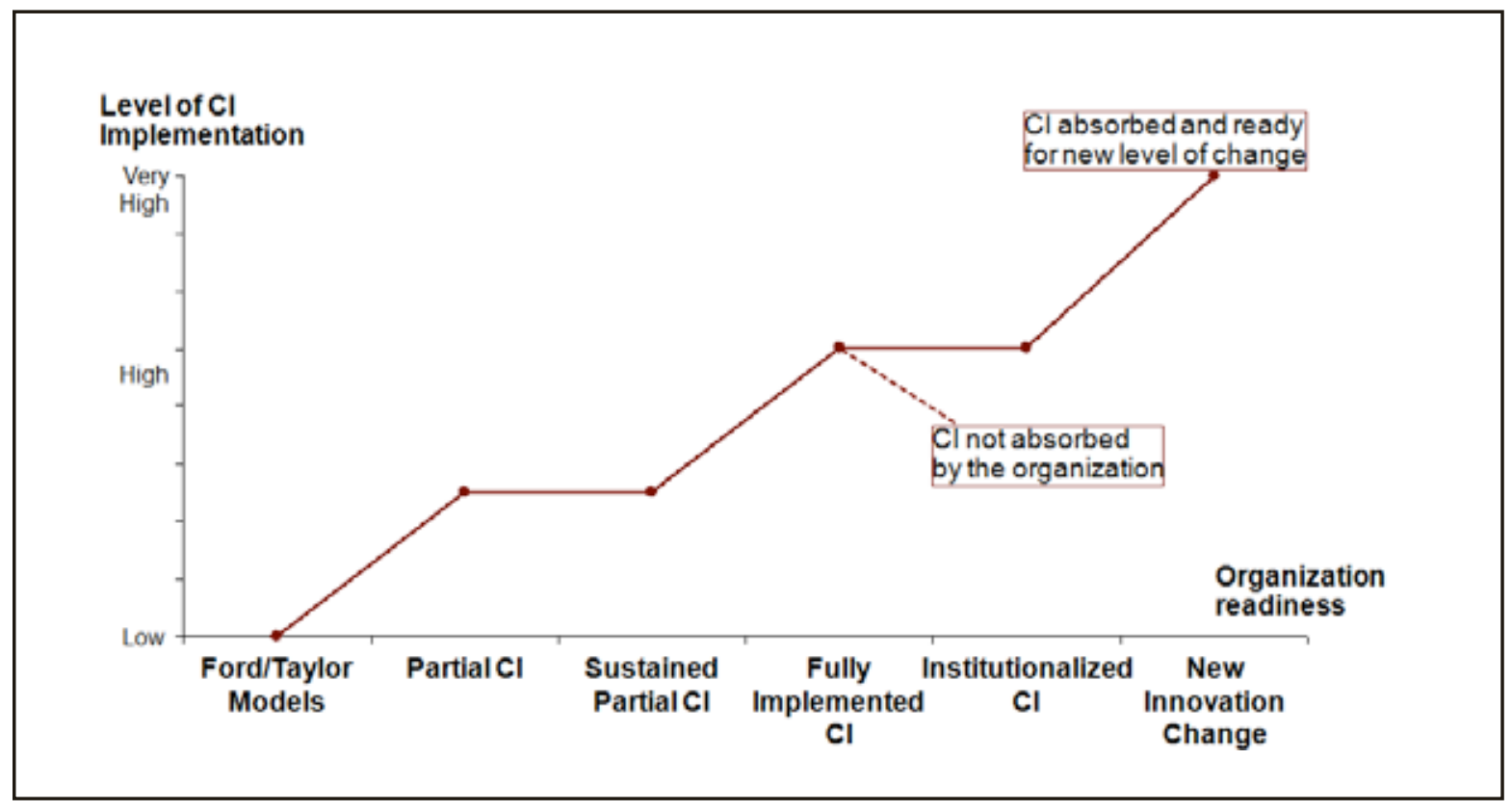

Picture I: evolution of manufacturing processes over time

In a case study, Silva (2003) promotes that organizational learning is a key factor in the effectiveness of programs for continuous improvement of production, addressing its cultural, behavioral and technical focuses. The author also noted that the partial evolution of the case study was positive, but not enough to bring about a "cultural change" and the consequent absorption of a continuous improvement culture.
This study aims to analyze the improvements in manufacturing processes, evaluating evolution of tacit and non-tacit results over time, barriers encountered in implementation, maintenance and institutionalization of the program of $\mathrm{Cl}$ in some cases of selected industries. 


\section{Theoretical Foundations}

The evolution of production systems is showed, (Morgan, 1986), through metaphors over time, the organization as a machine in Ford times, the organization as a body with the ascension of the Japanese (Toyota) and more recently the organization as a brain with practices of the autonomous production management in Volvo. In this context, it is clear the growing demand for knowledge and the consequent need to increase learning of organizations as a whole. In the wake of the three dimensions implicit in this process of economic and social change, knowledge - innovation - learning, several authors have been discussing models that are mostly found in two major research themes: on the one hand, change management, because we understand that this triad has led organizations to continuous movement of changes in their processes and products: and on the other hand, the school of learning that seeks to understand the organization with its structures focused on lifelong learning to incorporate knowledge and create innovations.

\section{I Change Management and Learning Organization}

The most recent literature on change management, according Woody (1995) has sought to show how the quest for high performance in Japanese organizations has affected the Western world. The author makes an analysis of changes in the Brazilian environment, which has a low propensity to change and low entrepreneurship, for historical and cultural reasons. This requires managing the aspects of change in a hybrid way, archaic and new, in the business environment in Brazil.

Is important to consider that it is the sensitivity to the cultural and behavioral, attributes for implementing programs of $\mathrm{Cl}$ and the consequent change management that are needed. Moreover, it is also important to analyze the past and the existence of relations of trust and cooperation for effective change, according to Woody (1995).

Therefore, in the implementation and maintenance of programs of $\mathrm{Cl}$, managing change and ensuring the organizational learning at different levels are important challenges to be met to enable the incorporation of the innovations of process improvements, product and business models routinely in the organization along with trying to understand the factors that contribute to learning and change management.
The failure of many programs of change after some time due to the difficulty of collective learning (Senge, 1999), besides, it is necessary to think systemically, as described in his book on the dance of change. Systemic thinking is based on a growing body of theories about the behavior of the feedback and the complexity - the tendencies inherent in a system that lead to growth or stability over time. Each person learns in a different way, so understanding the systems and behaviors involved in a process of change is necessary so that it lasts.

A study of the process of organizational learning and business performance (Perin et al, 2006) lists the types of organizational learning studied by several authors and concluded that for learning to occur, organizational learning is necessary to highlight the learning of single and double cycles to maintain competitiveness of organizations over time. In this list of authors, (Argyris \& Schon, 1996), ( Probst \& Buchel, 1997), (Senge, 1999) stand out among others, where learning of simple cycle is identified so that the organization can adjust to environmental factors and double learning cycle the process of creation or innovation, questioning rules and therefore leveraging process improvements.

Reinforcing the idea of learning, (Huber, 1996) describes that the organization that learns makes its increased performance also be accelerated, through its own experience, hiring people with desired knowledge, also by forming alliances, among other ways. Anyway, all this learning will provide a change of behavior in an appropriate environment to generate knowledge, learning and innovation.

The learning process can be evidenced in the process innovations as well as in technological innovations. A study conducted (Aiman-Smith \& Green, 2002) showed a complex relationship between kind of technology to be implemented, learning activities and results of implementation. Typically training planned in a systematic way is used in the process of implementing new technologies, however the author recommends that training be considered carefully by the leadership, because if users are not committed to technological change, they may resist, lower the speed of learning or even boycott the process of technological change. 
An environment for change becomes necessary. In literature various barriers and initiatives to minimize them have been discussed, as illustrated in Table I.

According to (Borda et al, 2007) the historical effect of organizations that prevent or impede the process of change can be reflected in the behavior and attitudes of those involved. The history/background of poor manage- ment of change, results in loss of confidence from staff in the management and in their ability to conduct the change and to safeguard their interests. Therefore, according to the author, low trust leads the employees to low job satisfaction and consequent increase in intention to leave the organization. Hence we can infer that such an environment cannot be conducive to the perpetuation of an environment of innovation and continuous improvement.

\begin{tabular}{|c|c|c|c|}
\hline & Communication & Behavioral & Participation \\
\hline $\begin{array}{l}\text { Rodrigues et al } \\
\text { (2004) }\end{array}$ & $\begin{array}{l}\text { Inadequate metaphors t } \\
\text { show transformation }\end{array}$ & $\begin{array}{l}\text { Low confidence related to } \\
\text { the interests of employees }\end{array}$ & $\begin{array}{l}\text { Resistance to skills / } \\
\text { competencies } \\
\text { development }\end{array}$ \\
\hline $\begin{array}{l}\text { Borda et al } \\
\text { (2007) }\end{array}$ & & $\begin{array}{l}\text { Low confidence regarding } \\
\text { the background to change }\end{array}$ & \\
\hline $\begin{array}{l}\text { Wanberg \& } \\
\text { Banas (2000) }\end{array}$ & Information & $\begin{array}{l}\text { Resilience (self-esteem, } \\
\text { optimism, perceived control) }\end{array}$ & Social support \\
\hline $\begin{array}{l}\text { Jiemmieson et al } \\
\text { (2004) }\end{array}$ & $\begin{array}{l}\text { Information and furthe } \\
\text { consultation with staff }\end{array}$ & $\begin{array}{l}\text { Intent to support the change } \\
\text { and reference of the group }\end{array}$ & $\begin{array}{l}\text { Creation of social } \\
\text { pressure among } \\
\text { people so that they } \\
\text { participate }\end{array}$ \\
\hline $\begin{array}{l}\text { Geppert et al } \\
(2003)\end{array}$ & & $\begin{array}{l}\text { Cultural aspects are not } \\
\text { potentiated }\end{array}$ & $\begin{array}{l}\text { Standardization } \\
\text { of practice } \\
\text { globalization }\end{array}$ \\
\hline
\end{tabular}

Table I: Barriers noted in processes of change

The issue of trust as a barrier to managing change in the environments has been analyzed in the literature in several ways. Environments that do not have poor history of change may also develop negative aspects of the trust during the process of transformation, implementation of change. One example was the study conducted by (Rodri- gues et al, 2004) in a Brazilian company that went through the privatization process. In this case, organizational learning which is a powerful weapon in the process of change was not of collective interest, becoming a factor of rupture between management and employees, instead of building trust between them. 
The study of these authors in Table I showed that skills development in the new organizational structure was no longer a learning process when individuals saw their interests threatened, as well as the continuity at work or function assigned. In addition, the communication process of the leaders, showing that the company needed to evolve out of a dinosaur into a bird, or similar metaphors, or until the development of skills and abilities should make the employee more employable, did not help in the process of trust and change.

In his study Jiemmieson et al (2004) confirms that communication and participation are important predecessors of the preparation for change. Regarding communication he also found a significant correlation between communication and the intention of promoting change in people's behavior, which encourages organizations to structure for this process. The author also noted that in the process of communication it is important the presence of the cycle of informing and consulting employees as a way to involve them in the process of change so that they do not resist such change.

The whole process of encouraging people, communication and behavioral initiatives of belonging to a group and creating references promote social pressure on those involved in order to make them participate more effectively in the process of change.

A behavioral analysis conducted by Wanderg \& Bana (2000) looking at the issues that impacted the opening of people to organizational changes. They noted the importance of issues related to participation, social support from the group and availability of information in the processes of change. In addition to these aspects analyzed, the aspect of behavioral resilience was observed in greater depth (self-esteem, optimism, perceived control), showing that individuals with high levels of resilience are better able to participate in processes of change than those with low resilience.

In addition to case studies and related research, it is important to mention psychologists, educators and their theories about learning, (Rogers, 1978), (Piaget, 1978), who reinforced the importance of language as a form of action, problem solving, teamwork and communities of practice as important mechanisms of learning in the learning process which are necessary on a daily basis.
Other evidence of the importance of managing change in organizations is the number of reports, and projects conducted in that environment. The reports of management consultancy (Isern \& Pung, 2007; McKinsey Quarterly, 2008) observed that the processes of change and transformation organization are directly related to cost reduction, with high energy level of the participants in the short term, obtaining in most cases, positive financial results. A strong process of communication is recommended, with sound history, and clear goals, which is something not always used by organizations. However, a great deal of the success of these programs is due to the discipline, transparency, communication and participation in leadership. In these projects we also observed a mixture of emotions, positive and negative behaviors in this environment: from anxiety, fatigue, frustration to excitement.

Generally what is grasped from the broader literature on the subject of preparing organizations for the context of innovations, through continuous changes, making them able to learn on an ongoing basis, applying the knowledge into new products, processes and business, is that conceptually the scenario is already set, however, there is a superficiality with regard to practical actions to institutionalize this conceptual framework in the organization over time. This is the focus of our research, which elects the operating environment as a fundamental means to institutionalize learning and innovation through continuous improvement programs. How to design programs of $\mathrm{Cl}$ for this purpose, which elements of alignment and distribution to use? Questions we plan to answer through an exploratory and qualitative research on representative cases of organizational change with a view to continuous improvement.

\section{Methodology}

We used the multiple-case study as a research strategy. In general, "case studies are the preferred strategy when 'how' or 'why' questions are being posed, when the investigator has a little control over events, and when the focus is a contemporary phenomenon within some reallife context" (Yin, 2003).

According to author, case studies may involve single or multiple cases and different levels of analysis. Depending on the number of cases, a study may be single-case or a multiple-case. Regarding the level of analysis, studies may be divided into embedded case studies, in which multiple subunits of analysis are considered, or holistic, in which 
the global nature of a single unit of analysis is examined. In fact, the multiple-case study shall be designed following the principle of replication logic, not a sampling logic. Then, if similar results are obtained from all cases, replication is said to have taken place. This replication logic is the same when a critical experiment shall be repeated. It is limited to a few cases due to being expensive or to difficulty in finding the cases.

Exploratory research is useful when little information is available to those in charge of decision-making, (Hair, 2005). When well conducted, exploratory research can provide a window into perceptions and behaviors. It is particularly useful in identifying innovative production and management practices.

We chose to conduct our research as an exploratory one. The multiple-case study follows an embedded design, involving more than one unit of analysis, because it included several outcomes from each company, qualitative and quantitative analyses of a large number of aspects of Continuous Improvement $(\mathrm{Cl})$ programs implementation, maintenance and consequently institutionalization. Several aspects were evaluated: leadership role, communication and participation practices, behaviors observed during interviews, factory tour and data analysis. The data for the study was collected from different sources in each company, using semi-structured interviews with professionals and observational participating in internal process management. Leadership and line workers were interviewed to discuss results, initiatives, and practices for a period that encompassed approximately $3-4$ years or more.

The study was made in a longitudinal period, the period enough to understand the implementation, results and changes over time.

\section{Research And Data Analysis}

For the proposed research three companies were selected - multinationals, with a strong performance in Brazil in the area in which they operate. In all three cases the process of implementing and managing continuous improvement programs have been part of their routine for years. For various reasons the companies studied in programs of this size have proven difficult to remain and be incorporated into the routine of management.

\section{I. Confectionary plant}

The case presented in this section was conducted in a plant of a global company that produces confectionary, candies, chocolate and gums. This is also a market leader in several segments worldwide. The research was conducted during the period of 2006 to 2008, a shorter period than the other two companies. What was observed in this company was a program of $\mathrm{Cl}$ that attained average performance in a period of two years, but with a tendency to decrease in the year following implementation, failing to maintain the results achieved in the subsequent year.

The plant of the confectionary company in Brazil was acquired two years before the start of continuous improvement activities. Most people stayed in the company after the acquisition. The previous organization did not have any program or culture of $\mathrm{Cl}$.

The continuous improvement program aimed to unify indicators and practices of $\mathrm{Cl}$ in the factories of Latin America. Some indicators such as improvement of productivity, efficiency, waste reduction, reduction of accidents and consequent cost reduction were targets predetermined by the regional organization.

The communication process for the entire plant was done quarterly, without communication processes daily, weekly or monthly with production groups. The history of change reported for the plant with about 1000 people was not structured to involve them, and the reduction of people caused threat to the interests of workers, reducing their confidence in the company.

The financial results achieved in the first two years exceeded $30 \%$ of growth compared to previous years, later with more aggressive goals for the next year coming from the global corporation. 
The leader of the project combined the role of maintaining the plant, which was also changing practices of control and maintenance to support process improvements, and had an employee dedicated to the improvement projects. Moreover, the industrial park contained approximately $30 \%$ of very old equipment, which required greater investment of remodeling or replacement, making stability difficult to achieve in the results of performance.

Due to the short time to achieve the cost reductions defined in the first year, the leadership trained a small group of engineering, maintenance and production to implement indicators, define the initiatives that would bring major benefits in the short term and shared practices and results with other plants in the region.

In this context it was observed that the speed of implementation for a largely populated organization, with few resources dedicated to the process, did not allow for proper involvement of the organization in the decisionmaking process of the program, because the interaction with the changes was restricted to a specific group and most people did not understand the indicators and results published in the panels of the factory, and even fewer understood, they were too far to foster confidence. The limited involvement of leadership in the search of very fast results, without management tools that would help in employee involvement, affected the results achieved and the stability to achieve a level of absorption and incorporation of $\mathrm{Cl}$ tools.

It became clear in such context that the learning process must involve all levels of the organization to create a solid ballast for maintenance and evolution of the results, probably due to the number of people and urgency for quick results. At the end of this cycle, motivated by the results achieved previously, the company sought to understand the learning barriers faced in the process of evolution of the $\mathrm{Cl}$ to propose a new way to approach and continued innovation in processes of $\mathrm{Cl}$, addressing the behavioral aspects, communication and effective participation of the organization in the process of change.

\subsection{Cosmetics, Fragrance and Toiletry (CFT) plant}

This study was conducted with an evaluation of an organization trajectory of a cosmetic company in Brazil. This company is among the three major players in the Brazilian cosmetic market, with international participation as well. The research was related during the period of 2003 and 2008, during a continuous improvement programs implementation based lean principles theory and shop floor semi autonomy.

The industrial plant of CFT had more than 1500 people and a large number of production equipment. The company had a low investment in infrastructure and modernization of production management, with a poor history of improvement programs. In interviews conducted with the leadership and workers at the plant it was identified that the previous programs had low participation in decision making, learning of work tools, as well as failed and distorted communication. Therefore, low interaction of people with the change itself, manifested in an estrangement from the facts, was also present.

Despite being a global organization, plants had autonomy of operation, when the activities of $\mathrm{Cl}$ began. Due to the history of the plant, a planning process was drawn, with tools to implement process improvement, leveraged by kaizen and $5 \mathrm{~S}$ events, change management with the support of the communication process daily, weekly and monthly, review of positions and skills needed for each function, training of team work by setting indicators (KPI's) to accompany each group of production, definition of necessary training - from troubleshooting to basic education; TPM program (Total Productive Maintenance), among other developed tools.

A pilot of the program implementation was conducted in order to build confidence in production, in the management and in their ability to change. Strong support of the leadership was shown, with the development of stories and metaphors of transformation in production. With the implementation of the pilot, a social pressure was created among people, leveraging the process of change and achievement of results, valuing the most resilient people in the process of change. Participation Programs in financial results were also prepared. 
The results of the pilot were leaders with more than $70 \%$ of improvement in productivity and efficiency of the involved areas, among others such as quality, safety and environment. This way, the rest of the plant began to move into the implementation process in stages, with a large number of planned training, preparation of equipment by maintenance and dedicated team of support. For 2 years the results still remained very expressive, even though only $50 \%$ of the factory had made the implementation.

Despite the acceleration and completion of the implementation process in the third year, the time devoted to learning was not the same, reducing earnings and causing frustration. During the interviews it was observed that over time new programs originating from the global organization such as ISO 900I, ISO 14000, Quality System, modernization of the industrial park that had about $50 \%$ of the equipment needing remodeling or substituting, implementation of new IT operating system, began to compete with the resources dedicated to the program of $\mathrm{Cl}$. Soon, planning change distanced itself from the operational and bureaucratized the process that was more organic, not keeping the same energy during the long process of implementation. This contrast is seen on the side effects and symptoms that were described by those interviewed by several factors. In the process of globalization in the areas of supply chain, for example, was the diversion of attention and focus of leadership, including bringing conflicting goals and misaligned areas of production partners. In the aspect of personal interests, respondents also said that the plan still co-existed with gap from the past, still unresolved, causing discontent among the teams.

This case study showed that there was a considerable recovery of the production team in building the MC program, supported by processes of communication, participation, clarity of intention to change the leadership and participation. The intensive program of education and training practices of $M C$ to basic educational requirements to shop floor was sustained for the gap of knowledge and learning between the teams. However, the delay of completion of training due to threat of other initiatives hampered the learning of several initiatives consecutively, impacting the achievement of the objectives stated in the program and leading it to deterioration. This shows that the consistency of the program and focus on the performance of specific actions over time are fundamental to motivation and maintenance program. In addition, the learning process and institutionalization of the process does not happen in an automated way people's behavior, learning and incorporate the changes in individual and differentiated in that practice through interactions with the facts they intend to change.

\subsection{Commercial Vehicles Assembling - CVA}

This case presented was studied in a plant of global player that produces commercial vehicles in Brazil. The research was performed during the related period of 1995 to 2008 , during a continuous improvement program implementation, based on lean principles theory. In the initial phase, from 1995 to 2002, the Brazilian board had autonomy to make decisions aiming at the recovery of profitability. Thus, in 1995 hired a very experienced consultant - a former manager from Toyota - of an international consultancy firm, who started a Kaizen program at CVA to replace the mass production paradigm embedded in the bureaucracy mindset by the principles of lean production system.

During this phase, major causes of wastes were identified and reduced/eliminated through the realization of approximately 3500 kaizen workshops involving most of the firm organization. The success accomplished in this effort was acknowledged group-wide and the plant received many visits of managers from other business units around the world. The transformation into a lean organization was the main objective of the firm, thus other functions than manufacturing were involved in this process including the planning departments responsible for Development, Facilities, Technology, and Strategy. As a result of this, the dissemination of lean thinking triggered a profound paradigm shift in the firm.

In 2003, the second phase started under new directives set by the board: the change process and diffusion of the new model would continue, though without the support of external consultants.

The headquarters began an intervention in the Brazilian board. Gradually the autonomy was reduced. First, the sponsor of the consultant in Brazil was retired and his substitute was not appointed by him, but by the CEO. It was the first in a sequence of substitutions and there were no more sponsors of lean in key positions or first level management. The new managers knew the lean as a set of tools, and several actions were taken in order to take 
the lean paradigm as a set of tools: the contract with the consultant was canceled, the kaizen management office and its internal specialists were dispersed, the managers did not consider the lean as central question any longer, but a mere tool.

In 2004 the lean production system was restricted in production and standardized in all units worldwide, together with a bureaucratic perspective. The audit was created and sets of 69 tools were verified in periodic audits. The Brazilian unit won the annual award of production system despite the auditor wanting documents and registers proving the system. Contrary to Toyota, in this company, even if the staff member is able to show that the principles were applied, without documentation he is not considered compliant with such principles.

In 2006 a consulting firm specializing in the auto industry was contracted and showed a detachment of lean production practices regarding the improvement of the results. The system became restricted to itself as a bureaucratic practice. A makeover then, began. The set of tools was not abandoned, nor the verification audits, continuing bias still bureaucratic of having all the improvements recorded, following standard procedures with evidence in documents. However, they introduced the principle that improvements in results, the indicators in general, needed to be emphasized and related to lean practices. There was then a recovery in the system since it abandoned the focus only on the document as evidence, but to having it as a means to achieve results. Thus the internal and external auditors of the lean program started targeting continuous improvement of the whole process. They focused on the process, its results and what tools were used to achieve such improvement. That made the program stops its degradation and start the recovery process.

Through interviews with middle managers carried out in 2009 we realized that historical movement were recognized by the participants. But mostly they are managers who are not involved in the first implementing movement in 1995 to 2000 and for this reason many consider that currently the level is higher than it was in the first phase. We chose the intermediate account of some specialists and managers to both contemporary periods who still consider the current stage below the continuous improvement system implemented in early stages of lean. The reason for the choice relates to justify this: the current system of continuous improvement moves under the tutelage of a strong control, almost coercive in that the tools must all be linked to income, while in the earlier stage when it reached its apex the improvements were pulled by teams that had to meet performance goals, and chose the tools of lean freely and spontaneously to reach them, very differently from the current stage in which the application is through a control system of continuous improvement set as a requirement that the developer did not use that or other tool or not properly used or not used as it should, in short, a series of coercive aspects in order to take up the use of something that was spontaneous.

\subsection{Data Analysis}

In general, the cases demonstrate that continuous improvement was developed more discontinuously than in a linear and always upward manner. A number of barriers acted as the inertia force that acts on the object wanting to prevent a new trajectory. At first, the novelty, the innovation, the surprise factor seems to act on all and on the organization that always shows some improvement. People in leadership groups, involved and committed move the others and the organization embraces new procedures that enable the beginning of learning.

However learning or is not complete or was superficial and the organization has a backlash/reflux. In all three cases we see this. The reasons relate superficially to the classical barriers of bureaucracy (CVA), misalignment of internal competition of programs (CFT) and isolated groups with no support (Confectionary) linked in a greater or lesser degree to collateral factors: poor or inappropriate communication, resistance from leaders, changes of staff members and loss of knowledge, change of leaders, lack of confidence in management and lack of support or infrastructure. They are all the classic reasons found in studies of literature and in interviews here. However, why do these barriers always emerge? Would there be no management of changes? Management assumes the existence of control and the emblematic case of CVA, management detected the decline, intervened and managed to reverse it, but did not reach the same enthusiasm seen in the initial phase. Few understood the system as a way of learning and innovation.

The literature has already addressed a number of barriers and levers of improvement programs, as well as the manufacturing. Literature has also addressed similar themes in this process of change management. 
In the cases studied, we also observed the need for a set of initiatives, planning and monitoring the change in order to build institutionalization without setbacks. All cases made up a Plan with controls and targets, but were not sufficient towards institutionalization.

In the case of the confectionary company, despite the achievement of the goals initially set by the organization, due to lack of transparent communication process, as demonstrated previously (Rodrigues et al, 2004), (Jiemmieson et al, 2004),(Wanderg \& Bana, 2000) not only did it fail to sustain the program but also caused resistance in teams. Moreover, the learning limited to a small team failed to foster advancement in the program as expected, as identified by Silva(2003).

The three case studies are described below and summarized in Table II.

\begin{tabular}{|c|c|c|c|}
\hline & Confectionary Plant & CFT Plant & CVA \\
\hline $\begin{array}{l}\text { Performance of } \\
\text { CI } \\
\text { Implementation }\end{array}$ & 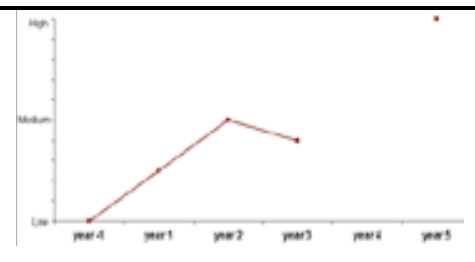 & 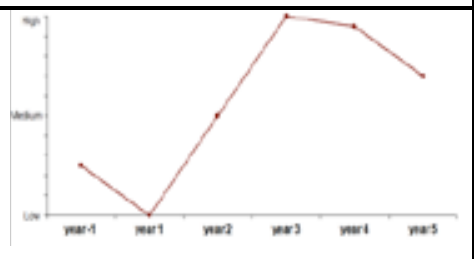 & $n=1 \quad n=2$ \\
\hline Barriers & $\begin{array}{l}\text { Low trust due to lack of } \\
\text { transparency of job reduction } \\
\text { objectives } \\
\text { High hierarchic organization. } \\
\text { Poor communication tools } \\
\text { Poor involvement of floor } \\
\text { workers, low autonomy } \\
\text { Limited results achieved due to } \\
\text { few people involved and around } \\
30 \% \text { of obsolete equipment }\end{array}$ & $\begin{array}{l}\text { Poor history results } \\
\text { Long CI roll out process f, too } \\
\text { many company global } \\
\text { initiatives at the same time and } \\
\text { around of } 50 \% \text { of obsolete } \\
\text { equipments } \\
\text { Complex training and education } \\
\text { process. Hybrid process } \\
\text { Workers salaries differences } \\
\text { Poor Supply Chain objectives } \\
\text { alignment }\end{array}$ & $\begin{array}{l}\text { Hierarchical and centralized } \\
\text { culture. } \\
\text { Lack of trust } \\
\text { Bureaucratic processes } \\
\text { Resistance from middle } \\
\text { management. } \\
\text { Turnover of the management and } \\
\text { coordination of the program. }\end{array}$ \\
\hline Levelers & $\begin{array}{l}\text { Supply chain aligned objectives } \\
\text { Quick and simple training tools } \\
\text { and sections } \\
\text { Few KPI's } \\
\text { Waste reduction and safety } \\
\text { practices improvements }\end{array}$ & $\begin{array}{l}\text { Communication process (daily, } \\
\text { weekly, monthly) and } \\
\text { understand level check } \\
\text { Middle management } \\
\text { involvement } \\
\text { Social pressure among } \\
\text { employees } \\
\text { Group work, 5S, safety and } \\
\text { waste reduction practices }\end{array}$ & $\begin{array}{l}\text { Corporate Objective } \\
\text { KPIs Monitoring } \\
\text { System Standardization } \\
\text { Trustworthy Consulting in the 1st } \\
\text { Stage }\end{array}$ \\
\hline
\end{tabular}

Table II: Three selected cases: results overtime, barriers and levelers identified. 
J. Technol. Manag. Innov. 20II,Volume 6, Issue 2

In the CFT company, since there already was resistance from prior production teams as well as from the leadership, they sought to follow the steps of planning, pilot training and team formation, but these were not sustained over time in the potential invested by leaders of the globalization process of manufacturing in the company, besieged/harassed by parallel programs and organizational changes that misaligned the objectives of the partner areas.

It would be tempting to say that the planning of the reported cases was not sufficient to predict or provide for all the design barriers and levers and neutralizing factors of the resistance. Nonetheless, such obstacles and interpretations arise after the facts, after time, master of things, gives us the distance to such ramblings. In fact, something more hidden and central in the findings is the fact that changes are emerging, that is, not everything is possible to plan. As Mintzberg (1994) criticizes the strategic planning for being a story that is justified after the facts, planning for change to actually contribute to the management of institutional change must recognize its limits.

This is the basic and fundamental item/data found here. The management of change and the continuous improvement programs as such cannot be planned in all its obstacles and factors of leverage. The case studies show the traditional barriers, but with form and diversity of content that they perceive as collateral for something more central. We propose to place such factors as supporting the research and to focus our efforts on working models of practice of continuous improvement at all levels in a way that will create the learning and innovation as well as knowledge. Focusing research on how to ensure that everyone can make improvements depending very little on the systems, on distant support or on difficult-to-obtain authorizations, that is, to bring continual improvement closer to day-today life of every organization in the factory floor and in the offices. Toyota is still an example of the image that we set as a priority in the management of change: planning ways for everyone to access the continuous improvement and take advantage of/enjoy it. It was precisely the lack of interaction between the operational public and their leadership with the objects and means of change that led to their detachment from reality and, hence, the side effects collected from the interviews: lack of communication because I see nothing, only hearsay, lack of trust - because I know nothing, only hear different and new words, and so such barriers go on.

\section{Conclusion}

Even if the data collected here indicate as main conclusion that planning for change should be focused on promoting a network of organizational interactions where what we want to change and with which new means we want to introduce them, leading to continuous improvement, leaving as auxiliary and emerging factors the treatment of barriers or stimuli to behavior, the fact is that some of these factors must be clearly thought out and planned in general terms to enable and facilitate the answers to the problems that emerge from the interaction. The difference is that they should be seen as emerging to facilitate interaction in a given organization rather than as pre-defined models that should be pursued to achieve the expected result. In short, they are a function of the interaction and a non-interaction function of them.

I. Interactive Leadership: mobilization of leadership for achieving quantitative targets for improvement through the interaction between the members of their teams having results in line with the organization.

2. Interactive communication: create a communications program that reaches all audiences involved with ascending and descending news on the operation and the language of actors, often enough not to miss the timing - the elements of communication daily, weekly, and monthly shall be constructed.

3. Means of Organizational Interaction: This can be accomplished in several ways: creation of project team, core team and steering team - with regular meetings involving interfaces, improvement teams, floor workers and leaders.

4. Interactional capabilities: the organization must be capable in carrying out the interaction sector, through technical training and behavior on the job and in teams.

5. Interactive performance management: process management and monitoring following not only the results of processes of interaction, but especially if the results were achieved with the new procedures.

6. Processes and technologies: equipment and processes need to be at least adequate to the needs of the business. The stability of the equipment in the production process is key to stability of the new procedures and their interactions. 
7. Infrastructure: systems and data should facilitate interactions at all levels. Avoid blocks of information to the actors, apart from what is confidential.

Observing the three $\mathrm{Cl}$ programs case studied presented, all of them have declined the positive results trends observed after start up, and somehow the barriers were not treated in a way to continue improve the program performance and credibility as before, although it is difficult to generalize the analyse. Finally, the institutionalization of $\mathrm{Cl}$, aiming to give basis to innovation and lifelong learning throughout the organization, before seen as a process planned in all its details and phases, we propose here to see it as a process partially planned, in what is more fundamental: to enable the interactions between members seeking continuous improvement and to disable the stagnation or retrogression. In a speculative way, because this was found in none of the companies; on the contrary, the interactions were bureaucratized (the CVA case), partial and isolated (confectionary) and misaligned and broken (CFT), so depending on what we have seen here in construction of a vision of what might enable interactions arising from the continuous improvement:

- Leadership designed to teach and having as a goal, group training, teaching, enabling of improvements through people. - Support workshops or laboratories which are open for employees to put ideas or improvements into practice. Having the satisfaction of being able to implement minor improvements without bureaucracy. "I can do." "Yes, we can". - Alignment of organizational goals with individual goals by fostering the detection and disclosure of problems that are in the way of expected results. Identify, understand, disseminate and seek solutions to problems of alignment across teams.

- Establish interactions between a bank of issues and a bank of ideas and solutions. Conventionally everyone thinks of solutions and ideas, but real learning comes with a problem to solve. Motivate the detection of problems as a way to stimulate creative thinking.

- Simple visual management as a means of transparent communication of what is being done regarding improvements, the status of the situation, and what still needs to be improved. Viewing and enabling others to see the bank of problems in each sector.

- Encourage, through goals, the formation of systemic or multidepartment groups to solve systemic problems. Some problems involve Production-Engineering-Purchasing, ultimately involving several sectors at the same time.
The question should be: "Have you ever solved a problem with your colleague from another sector?" motivate the interaction that will culminate in improvement.

- Simplify the portfolio of tools used to improve processes and frequently analyze the understanding of the teams regarding the learning process, through an intense process of communication.

If by means of these and other initiatives, the organization focuses on interaction for continuous improvement, obstacles will emerge as well, but it will be a problem motivated by the interaction so that the wheel will turn towards continuous improvement. We do not want to give a recipe with such suggestions of procedural interaction, but only to illustrate our basic conclusion: The process of continuous change is an emerging institutionalized phenomenon and if thus considered and planned through the privilege of interaction among agents, the solutions against the pitfalls of bureaucracy, misalignment and breakdown will emerge. 


\section{References}

AIMAN-SMITH, L. \& Green. Implementing new manufacturing technology: the related effects of technology characterísitcs and user learning activities. Academy of Management Journal, v. 45, n. 2, p.421-430, 2002

ARGYRIS, C. \& Schon, D. Organizational Learning: a Theory of Action Perspective. Massachusetts: AddisonWesley, 1996.

BORDA, P. et al. Haunted by the Past: effects of poor change management history on employee attitudes and turnover. Academy of Management Annual Meeting Proceedings: Doing Well By Doing Good, 3 - 8 August, Philadelphia, United States, 2007

CAFFYN, S. Development of a continuous improvement self assessment tool. International Journal of Operations and Production Management, v.19, n.II, p.II38-II53, 1999.

CHEN, C \& Wu, C. An integrated structural model toward succesfull continuous improvement activity. Technovation, v.26: n.5-6, p. 697-707, May - June, 2006.

CLARK, K. \& Fujimoto, T. Product development performance: strategy, organization and management in the world auto industry. Boston: Harvard Business School Press, 1991.

DELBRIDGE, R. \& Barton, H. Organizing for continuous improvement: structures and roles in automotive components plants. International Journal of Operations and Production Management, v.22, n.6, p. 680 - 692, 2002.

DRUCKER, P. From Capitalism to Knowledge Society in Neef, D. The Knowledge Economy. Woburn, MA: Butterworth -Heinemann, 1998.

FUJIMOTO, T. The evolution of a manufacturing system at Toyota. London: Oxford University Press, 1999.

GEPPERT, M. et al. Change Management in MNCs: How Global convergence interwines with National Diversities. Human Relations, v.56, n.7, p.807-838, 2003.

HAIR, J. et al. Fundamentos de Métodos de Pesquisa em Administração. Porto Alegre: BOOKMAN, 2005.
HUBER, G. Organizational learning: a guide for executives in technology - critical organizations. International Journal Technology Management, Special Issue on Unlearning and Learning for Technological Innovation, v.II, n.7-8, p.821 -832, 1996.

ISERN, J. \& Pung, C. Driving radical change in The McKinsey Quarterly Review, November 2007. Available in <http:// www.mckinseyquartely.com>. Access in 2010, September.

JIEMMIESON, N. et al. Employee readiness for change: utilizing the theory of planned behavior to inform change management. New Orleans: Proceedings of Academy of Management, Best Conference Paper, August 2004

MINTZBERG, H. The Rise and Fall of Strategic Planning. New York: The Free Press, 1994.

MORGAN, G. Images of organization. California: Sage Publication. 1986.

NELSON, R. Understanding Technical Change as an EvolutionaryProcess. New York:ElsevierSciencePublishers, 1987.

NONAKA, I. \& Takeuchi, H. The knowledge-creating company. New York: Oxford University Press, 1995.

OHNO, T. Toyota Production System: Beyond Large Scale Production. New York: Productivity Press, 1988.

PERIN, M. et al. Processo de aprendizagem organizacional e desempenho empresarial: $O$ caso da indústria eletroeletrônica no Brasil. São Paulo: Fundação Getúlio Vargas - Escola de Administração de Empresas de São Paulo, Revista RAE eletrônica, v.5, n.2, dezembro 2006.

PIAGET, J. Fazer e compreender. São Paulo: Edusp/Melhoramentos, 1978.

PROBST, G. \& Buchel, B. Organizational learning. London: Prentice Hall, 1997

RODRIGUES, S. et al. Aprendizagem contestada em ambiente de mudança radical. São Paulo: Fundação Getúlio Vargas - Escola de Administração de Empresas de São Paulo. Revista de Administração de Empresas, v.44, n.I, Jan/Mar de 2004. 
ROGERS, C. Liberdade para aprender. Belo Horizonte: Interlivro, 1978.

SENGE, P. The Fifth Discipline.The Art \& Practice of the Learning Organization. New York: Doubleday, 1990.

SENGE, $P$ et al. The Dance of Change. The Challenge to Sustaining Momentum in Learning Organizations. New York: Doubleday, 1999.

SILVA, B. Os programas de melhoria contínua como processos de aprendizagem: o caso de uma indústria de produtos alimentícios. Dissertação de Mestrado. São Paulo: Universidade de São Paulo, Faculdade de Economia e Administração, 2003.

MCKINSEY QUARTERLY. Creating organizational transformations: McKinsey Global Survey Results in The McKinsey Quarterly Journal, August 2008. Available in <http:// www.mckinseyquartely.com>. Access in 2010, September.

WANDERG, C. \& Bana, J. Predcitors and outcomes of openness to changes in a reorganizing workplace. Journal of Applied Psychology, v.85, n.I, p.132 - 142, 2000

WOMACK, J; Jones, D.; Roos, D. The Machine That Changed the World. New York: Harper Perenniall, 1990.

WOMACK, J., Jones, D. Lean Thinking: Banish Waste and Create Wealth in Your Corporation. New York: Simon \& Schuster, 1996.

WOODY, T. Mudança Organizacional. São Paulo: Editora Atlas, 1995.

YIN, R. Case Study Research. Design and Methods. London: Sage Publications, 2003. 
J. Technol. Manag. Innov. 20II,Volume 6, Issue 2 